\title{
Conditions at autumn stopover sites affect survival of a migratory passerine
}

\author{
Lucyna Halupka $^{1}$ (D) Kaja Wierucka ${ }^{2,3} \cdot$ Hanna Sztwiertnia $^{4} \cdot$ Ewelina Klimczuk $^{4}$
}

Received: 10 January 2017/Revised: 2 May 2017/ Accepted: 12 June 2017/Published online: 17 July 2017

(C) The Author(s) 2017. This article is an open access publication

\begin{abstract}
Weather is an important factor affecting many aspects of avian ecology, yet its importance for survival during various periods of the avian annual cycle has received relatively little attention and remains poorly understood. We have investigated the effect of weather conditions at the breeding and wintering grounds and during migration on the survival probability of Eurasian Reed Warblers Acrocephalus scirpaceus, a long-distance Palaearctic-African migrant species. We found that annual survival was significantly affected by precipitation at the autumn stopover sites in Spain and Morocco, where Reed Warblers accumulate energy reserves prior to crossing the Sahara desert: low rainfall was associated with decreased survival. We suggest that arid conditions at these crucial stopover sites may cause limitations in food availability, prevent proper refueling and hence result in lower survival.
\end{abstract}

Communicated by F. Bairlein.

Electronic supplementary material The online version of this article (doi:10.1007/s10336-017-1472-5) contains supplementary material, which is available to authorized users.

Lucyna Halupka

lucyna.halupka@uni.wroc.pl

$\triangle$ Kaja Wierucka

kaja.wierucka@hdr.mq.edu.au

1 Ornithological Station, University of Wrocław, Sienkiewicza 21, 50-335 Wrocław, Poland

2 Department of Biological Sciences, Macquarie University, Sydney, NSW 2109, Australia

3 Institut des Neurosciences Paris-Saclay, Université ParisSaclay, CNRS (UMR 9197), Université Paris-Sud, 91405 Orsay, France

4 Silesian Ornithological Society, Sienkiewicza 21, 50-335 Wrocław, Poland
Survival estimates were not related to weather conditions in Africa during the bird wintering period or the preceding wet season. Likewise, meteorological conditions at the breeding area did not influence survival. Survival estimates for males and females did not differ, although recapture probability was significantly lower for females than for males. Our results indicate that weather significantly influences Reed Warbler survival, although its effect may vary for different stages of the annual cycle. Our findings suggest that marked climatic changes occurring along migratory routes, in particular at important stopover sites, may have far-reaching consequences on bird survival and population size.

Keywords Annual survival - Meteorological conditions . Weather · Migration - Eurasian Reed Warbler (Acrocephalus scirpaceus) $\cdot$ Climate change

\section{Zusammenfassung}

\section{Die Bedingungen an den Herbstrastplätzen beeinflussen das Überleben eines ziehenden Singvogels}

Das Wetter ist ein wichtiger Faktor, der bei Vögeln viele Aspekte der Ökologie beeinflusst; dennoch wurde seiner Bedeutung für das Überleben während verschiedener Phasen des jährlichen Zyklus der Vögel relativ wenig Aufmerksamkeit zuteil und man weiß nach wie vor nur wenig darüber. Wir untersuchten die Auswirkungen der Wetterbedingungen in den Brut- und Überwinterungsgebieten sowie auf dem Zugweg auf die Überlebenswahrscheinlichkeit von Teichrohrsängern Acrocephalus scirpaceus, Langstreckenziehern zwischen Paläarktis und Afrika. Die jährlichen Überlebensraten wurden signifikant von den Niederschlagsmengen in den Herbstrastgebieten in Spanien und Marokko beeinflusst, wo 
die Teichrohrsänger Energiereserven anlegen, bevor sie die Sahara überqueren: Geringe Regenmengen standen mit vermindertem Überleben im Zusammenhang. Wir legen nahe, dass aride Bedingungen an diesen entscheidenden Rastplätzen eine begrenzte Nahrungsverfügbarkeit zur Folge haben können, welche ein richtiges "Auftanken" verhindern und somit $\mathrm{zu}$ schlechterem Überleben führen kann. Die Überlebensschätzwerte hingen nicht von den Wetterbedingungen in Afrika während des Überwinterungsaufenthaltes der Vögel oder zur vorhergegangenen Regenzeit ab. Ebenso wenig beeinflussten die meteorologischen Bedingungen im Brutgebiet das Überleben. Überlebensschätzwerte für Männchen und Weibchen unterschieden sich nicht, obwohl die Wiederfangwahrscheinlichkeit bei den Weibchen signifikant geringer war als bei den Männchen. Unsere Ergebnisse deuten darauf hin, dass das Wetter einen signifikanten Einfluss auf das Überleben der Teichrohrsänger ausübt, obgleich sich seine Auswirkungen $\mathrm{zu}$ den verschiedenen Stadien des Jahreszyklus unterscheiden können. Unsere Befunde legen nahe, dass ausgeprägte klimatische Veränderungen entlang der Zugrouten, speziell an wichtigen Rastplätzen, weitreichende Folgen für das Überleben der Vögel und die Populationsgröße haben können.

\section{Introduction}

Weather is an important factor affecting many aspects of the avian life cycle and its various parameters, including food availability, feeding behaviour, nestling growth and duration of the breeding season (Williams 1961; Geiser et al. 2008; Jankowiak et al. 2014), as well as survival of the young and adults (Polak and Kasprzykowski 2013; Winkler et al. 2013). Its effects may be both direct (adverse conditions and increased metabolic rates during migration) or indirect (e.g. manifested through changes in food abundance) (Newton 2006; Peach et al. 1991). However, despite the importance of the effect of weather conditions on survival during various periods of the avian annual cycle, this aspect of avian life-history has received relatively little attention and remains poorly understood.

During the last few decades large-scale climatic changes have significantly affected local weather conditions in many parts of the globe (Houghton 2015). As such, changes in weather parameters may occur at the wintering or breeding grounds, as well as at stopover sites (Halupka et al. 2008; Zwarts et al. 2009; García-Mozo et al. 2011). Large-scale climatic changes may also cause weather anomalies along the migratory routes (Tøttrup et al. 2012) that may affect the survival or population dynamics of various bird species (Sanderson et al. 2006; Ockendon et al. 2014; Inger et al. 2015; Jansen et al. 2015; Woodworth et al. 2017).

Most studies on the annual survival of migratory birds have found that survival largely depends either on factors that affect the breeding (Schaub et al. 2005; Robinson et al. 2010; Blomberg et al. 2013) or wintering grounds (Peach et al. 1991; Baillie and Peach 1992; Leyrer et al. 2013; Salewski et al. 2013; Woodworth et al. 2017). Nevertheless, a growing number of studies suggest that conditions encountered during migration may also be important for some species (Stokke et al. 2005; Newton 2006; Bayly et al. 2011), with a few studies providing evidence that mortality during migration may be higher than that experienced at the stationary stages (Ward et al. 1997; Sillett and Holmes 2002; Klaassen et al. 2014). These data coincide with occasional observations documenting substantial numbers of migratory bird deaths under adverse environmental conditions. For example, low temperatures and snowfall in late September 1974 resulted in the deaths of thousands of House Martins in the Swiss Alps (Stokke et al. 2005; after Ruge 1974).

Conditions at multiple stopover sites are important for species that gather food reserves along the migratory route. For some species, crucial stopover sites tend to be located close to a major barrier, allowing them to acquire energy resources just before crossing it. Examples of species using the latter refueling strategy are Eurasian Reed Warblers Acrocephalus scirpaceus and Common Whitethroats Sylvia communis: both species accumulate most of their fat reserves just ahead of crossing the Sahara desert (Schaub and Jenni 2000). Any adverse environmental changes occurring at these crucial stopover sites may have severe consequences for the survival of such species. To our knowledge, only a few studies to date have investigated and found some effect of conditions at stopover sites on the survival of migratory birds (Baker et al. 2004; Hewson et al. 2016). Baker et al. (2004) found that foraging conditions in Delaware Bay, an important stopover site for Red Knots Calidris canutus before their departure to their Arctic breeding grounds, deteriorated considerably due to the overharvesting of crabs whose eggs are the main food of the species there, resulting in a decreased survival of adults and, consequently, a population decline. Hewson et al. (2016) noted that the migratory Common Cuckoos Cuculus canorus, which breeds in the UK, experienced its highest mortality at stopover sites in Spain where climatic and environmental conditions have changed considerably in recent years, having become more arid as a result of climate change.

In the study reported here, we analysed the effect of weather variables on the survival of an Afro-Palaearctic migrant, the Eurasian Reed Warbler (hereafter referred to as Reed Warbler), throughout 8 years of the current century - a time period during which climate change has been 
accelerating at an unprecedented rate (World Meteorological Organisation 2016). Our aim was to determine whether meteorological conditions at the breeding and/or wintering grounds, as well as at stopover sites, influenced species survival.

\section{Methods}

\section{Study species}

The Eurasian Reed Warbler Acrocephalus scirpaceus is a small (12 g) long-distance migrant which breeds throughout most of the Palaearctic and winters in sub-Saharan Africa (Cramp 1992). Recent analyses suggest that Reed Warbler numbers are declining in Europe (Vickery et al. 2014, but see Ockendon et al. 2014; Inger et al. 2015). Procházka et al. (2008) demonstrated that Reed Warbler populations breeding in neighbouring areas of Europe tend to undertake similar migration routes and have wintering grounds in the same parts of Africa. Reed Warblers from central and western Europe are known to spend their winters in western sub-Saharan Africa, probably mostly near the coast (Zwarts et al. 2014). They migrate by alternating short periods of flight with longer stopovers, but they gain mass mostly at stopover sites in the Mediterranean area, just before crossing the Sahara (Schaub and Jenni 2000, 2001; Rguibi-Idrissi et al. 2003). Local observations and recent geolocator studies indicate that most birds begin the autumn migration in late July-August and reach their African wintering grounds in September-October (Andueza et al. 2014; Adamik et al. 2016; Araújo et al. 2016). In spring they undertake the return migration in March-May and reach breeding grounds in late April-early June (Arizaga et al. 2010). For birds using the western migration route through Iberia in the autumn, important autumn stopover sites (before crossing the Sahara desert) are located in Spain, Portugal and Morocco (Rguibi-Idrissi et al. 2003; Hama et al. 2013; Andueza et al. 2014; Araújo et al. 2016). Bayly et al. (2012) recently demonstrated that Djoudj National Park in northern Senegal is a very important stopover site for many species, including Reed Warblers, and is used intensively by the latter species, especially during the spring just before their migration across the Sahara desert. These authors suggest that at this time of year the area of the park and the remaining part of western Sahel may host about $67 \%$ of the western European Reed Warbler population. According to Zwarts et al. (2014) about $30-50 \%$ of the European Reed Warbler population (4-6 million birds) spend winter in mangrove habitats along the coast.

\section{Study population}

We studied a population of Reed Warblers breeding on "Słoneczny" pond in the Stawy Milickie nature reserve
(Milicz fish-ponds) in south-western Poland. The breeding season (defined as the time when birds have active nests) in our population lasts from early May until mid-August. The arrival of both sexes at our breeding site is asynchronous and occurs from late April until early/mid-June. Likewise, the departure period is prolonged, with some individuals leaving the breeding area in late July while others remain on site until late August or even September (L. Halupka, unpublished data). As a result, there is considerable overlap in the periods of migration, breeding and wintering of different individuals. Birds in our population show relatively high site fidelity between breeding seasons; this is similar for males and females (on average 38.5 and $52.5 \mathrm{~m}$, respectively; calculated for individuals returning to the study plot) and independent of nest success in the previous breeding season (L. Halupka, unpublished data).

Data from recoveries during the migration of birds marked in our breeding population and nearby populations suggest that they migrate through Germany, Belgium, France, Spain and Morocco and on through Senegal (Bairlein et al. 2014; Procházka and Policht 2008; Procházka et al. 2008; Bayly et al. 2012). Data on wintering sites obtained from the Polish Ringing Centre in Gdańsk, and data from nearby populations in the Czech Republic and Germany (Procházka and Policht 2008; Bairlein et al. 2014) overlap and suggest that birds from our population winter in the Ivory Coast, Sierra Leone, Liberia, Ghana, Togo and Guinea, probably mostly on the coast (Zwarts et al. 2014) in the humid wintering zone (following the definition of Ockendon et al. 2014; see: Fig. 1).

\section{Data collection}

The study of the breeding population of Reed Warblers was carried out between 2005 and 2013 on a 4-ha study plot located in the south-eastern corner of the "Słoneczny" pond (centre at $51.5385^{\circ} \mathrm{N}, 17.3390^{\circ} \mathrm{E}$ ). The plot was covered mostly by an extensive reedbed (up to $150 \mathrm{~m}$ wide), with patches of vegetation (common reed Phragmites australis fringed by cattails Typha angustifolia, with scattered patches of bittersweets Solanum dulcamara) separated by numerous bays and narrow paths. From early May (arrival of the first individuals) to late July birds were captured in mist nets, sexed by external characters (Svensson 1992) and individually marked using a combination of one metal and three-colour rings. The mist-netting effort was consistent throughout years, and we did not record any ring losses by birds. Resightings in subsequent years came from observations of birds within the study area (for further details, see Halupka et al. 2014a, b; Klimczuk et al. 2015; Orłowski et al. 2015). 


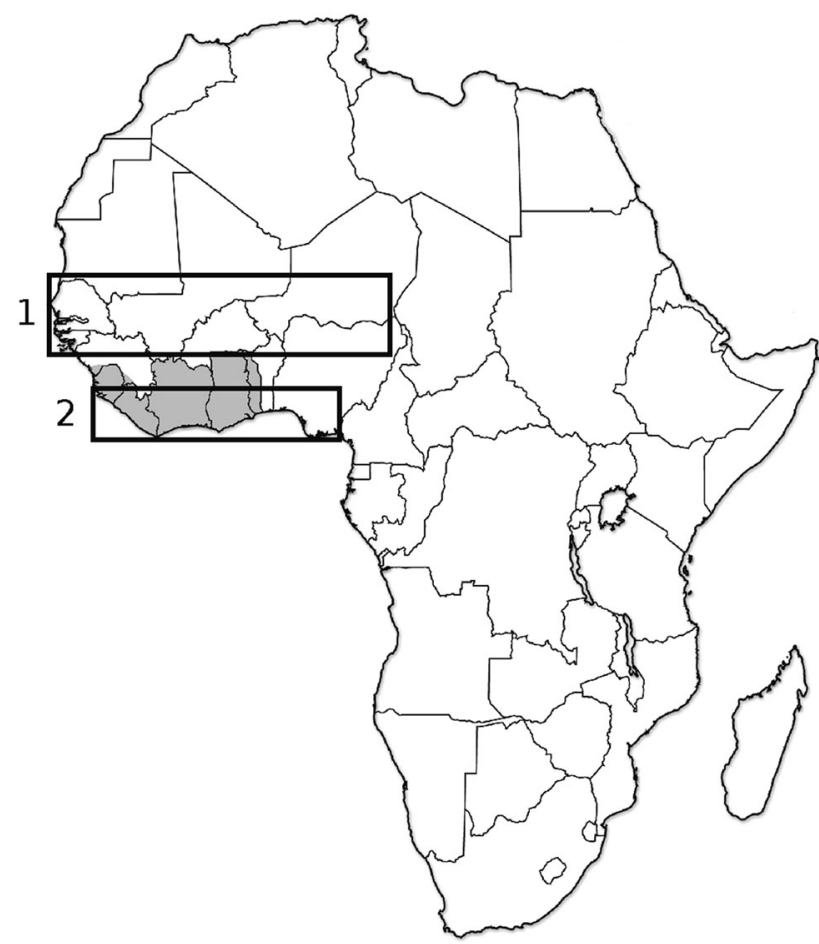

Fig. 1 Map of Africa showing presumed wintering areas of Reed Warblers (Acrocephalus scirpaceus) from our study population (grey areas) as well as arid (1) and humid (2) wintering zones (following Ockendon et al. 2014)

\section{Meteorological data}

We used temperature and precipitation variables to estimate meteorological conditions during migration stopover sites, as well as at breeding and wintering grounds. Furthermore, as the winter North Atlantic Oscillation (NAO) is strongly correlated with spring conditions in Europe, we used this index (following, for example, Gordo and Sanz 2008; Salewski et al. 2013) as a variable in one of our models to analyse the effect of weather conditions on survival along the migratory route.

Based on recoveries and published data available for the species we considered August-October to be the time of autumn migrations; October-March as the period spent at wintering grounds; and March-May as the time of spring migrations (Cramp 1992; Korner-Nievergelt et al. 2002; Balança and Schaub 2005; Procházka et al. 2008; Zwarts et al. 2014). The periods overlap as breeding, arrival and departure of individuals of the species are asynchronous (Halupka et al. 2014b).

For the analyses, we used mean temperatures and total precipitation during the given seasons. Meteorological data for the breeding season were collected at the study site, approximately $800 \mathrm{~m}$ from the study plot (Davis Vantage PRO 2 weather station; Davis Instruments, Hayward, CA). Meteorological data for the wintering grounds were obtained from the National Oceanic and Atmospheric Administration's (NOAA) National Centers for Environmental Information (data available online: http://www. ncdc.noaa.gov/). NAO values were obtained from NOAA's National Weather Service, Climate Prediction Center (data available online: http://www.cpc.ncep.noaa.gov/). We used data available at the Climate Change Knowledge Portal of the World Bank Group for both autumn and spring stopover sites (data available online: http://sdwebx.worldbank. org/climateportal/index.cfm). All data were standardised prior to being added to models.

Taking into account the information available on the wintering grounds of our and neighbouring populations of Reed Warblers (see preceding sections for details), data from 27 African meteorological stations were obtained in order to calculate meteorological data for the wintering area [the list of stations is available in Electronic Supplementary Material (ESM) Table S1]. We took into account the meteorological data from the period corresponding to the Reed Warbler wintering season (October-March), as well as the preceding wet season (May-October), as earlier rainfall levels may strongly affect conditions (e.g. food abundance) during the wintering period (see Ockendon et al. 2012, 2014). We used meteorological data from Senegal to assess conditions at stopover sites before the Reed Warblers crossed the Sahara during the spring migration (Bayly et al. 2012) and data from Spain and Morocco to assess conditions at the autumn stopover sites (Rguibi-Idrissi et al. 2003; Hama et al. 2013; Andueza et al. 2014).

\section{Statistical analysis}

Capture histories of Reed Warblers were created by pooling all sightings for each individual within a breeding season. Goodness-of-fit tests (GOF) were carried out in program U-CARE (Choquet et al. 2009). Cormack-JollySeber (CJS) models (Cormack 1964; Jolly 1965; Seber 1965) in MARK 7.1 (White and Burnham 1999) were used to estimate survival $(\phi)$ and recapture probabilities $(p)$.

The CJS model stands on the following assumptions (Pollock et al. 1990): (1) all individuals in a group have the same recapture probability $p$ at occasion $t$; (2) all individuals in a group have the same survival probability $\phi$ between occasions $t$ and $t+1$; (3) marks are not lost; (4) capture occasions are short in time compared to the interval between two successive occasions. The global GOF test for the basic model $\phi_{g \times t} p_{g \times t}$ [with survival $(\phi)$ and recapture probability $(p)$ varying between sexes $(g)$ and in time $(t)]$ proved to be significant $\left(X^{2}=46.949, \quad d f=26\right.$, $p=0.002$; c-hat $=1.805)$ and was a result of issues with overdispersion revealed by test $3 . \mathrm{SR}(p<0.001)$. These problems were accounted for by implementing a time- 
since-marking (TSM) model $\phi_{2 \mathrm{M}-t / t} p_{g \times t}$, where two marking classes are present, with the first (M1) class representing survival of individuals in the first year after marking, and the second class (M2+) representing survival in subsequent years. C-hat values were estimated to evaluate whether problems with overdispersion were still present following the structural adjustment of the model. This was measured by dividing the GOF $X^{2}$ value of the relevant tests from U-CARE by the degrees of freedom (Cooch and White 2012). The adjusted (TSM) model accounted for issues in the dataset, therefore meeting assumption 2 of the CJS model. GOF test 2.CT showed no trap-dependence ( $p=0.217)$, thereby confirming that our data met the first assumption. As already mentioned, we have never observed the loss of rings (marks) by birds in our population (assumption 3). Assumption 4 was met as all summer months (May-mid-August) were pooled together to form one capture occasion per year, and this period was shorter than the rest of the year (the period between capture occasions).

As all birds used in our analyses were ringed as adults, we were unable to determine their exact age. It is therefore possible that group M1 consists of (1) "true transients", i.e. adult individuals that were present in the study site during only one capture occasion (the site fidelity reported above was calculated only for individuals returning to the breeding site in consecutive study years, and it was not possible to determine this parameter for birds that did not return to the study plot), or (2) young adult individuals or first-year breeders (the transient effect in this case would be caused by higher dispersal or mortality of these inexperienced birds) or (3) both. As we were unable to ascertain the exact cause of high levels of overdispersion, we decided to separate these individuals (TSM model, group M1) and only consider the influence of meteorological conditions on annual survival rates of the "resident" population of Reed Warblers (TSM model, group M2+- experienced breeders observed regularly at the study site, with high site-fidelity) to obtain less biased estimates.

We considered various models of survival and recapture probability. We began with the basic model $\phi_{g \times 2 \mathrm{M}-t / t} p_{g \times t}$, where survival varied between sexes $(g)$; this model was divided into two classes $(2 \mathrm{M})$, with both classes as well as recapture probability varying over time $(t)$ and between sexes. We then fitted models for $p$ by constraining parameters to be constant in time (.) or between sexes. After obtaining the best model for $p$, we explored similar possibilities for survival. Later, to test for the influence of meteorological conditions on Reed Warbler survival, we created several models in which the time effect in $\phi$ for $\mathrm{M} 2+$ was replaced with meteorological values. We examined the influence of total seasonal precipitation $(P)$ and mean temperature $(T)$ on the wintering ( $W$, wintering months; $W_{\text {wet }}$, preceding wet season on wintering grounds) and breeding $(B)$ grounds, as well as during the spring (SM) and autumn (AM) stopover sites during migration. Additionally, we tested whether NAO winter values (NAO) influenced survival.

Akaike's information criterion corrected for a small sample size (AICc; Sugiura 1978; Hurvich and Tsai 1989) was used for model selection. The model with the lowest AICc value (with $\triangle \mathrm{AICc}>2$ ) was considered to be the best model. The influence of the climatic variable from the best model based on AICc values was additionally confirmed by performing a likelihood ratio test (LRT). Furthermore, we examined effect sizes (on a probability scale) of meteorological variables for all models including such variables.

\section{Results}

A total of 778 adult Reed Warblers (436 males and 342 females) were ringed and included in analyses. We began model selection with model $\phi_{g \times 2 \mathrm{M}-t / t} p_{g \times t}$ (Model 17, Table 1). When modeling recapture probability, a model with sex-specific recapture probabilities that were constant over time (Model 15, Table 1) proved to be the best fit for our data. Having found the best-suited model for $p$, we began exploring different models for $\phi$. A $\triangle$ AICc value of 5.459 between models 14 and 3 provides considerable evidence that models without sex effect were better suited for our data, showing no difference in survival estimates between males and females.

The best-suited model without added meteorological values was model 3 (Table 1), with survival constant over time and between groups. Survival for M2+ was equal to 0.443 [95\% confidence interval (CI) $0.380-0.508]$. The best-suited model for our data (model 1, Table 1) included precipitation variables from the autumn migration. Survival estimates for $\mathrm{M} 2+$ obtained from model 1 ranged from 0.340 (95\% CI $0.240-0.456)$ to $0.593 \quad$ (95\% CI 0.428-0.739), and annual bird survival was higher with increased total precipitation at the autumn stopover sites (Fig. 2). Recapture probability was significantly lower for females $(0.592$; $95 \%$ CI $0.433-0.733)$ than males $(0.883$; $95 \%$ CI $0.792-0.937$ ). AICc values ( $\triangle$ AICc between model 1 and $2=2.123$ ) provided considerable support for a difference between model 1 and the alternative models, indicating that precipitation during autumn migration stopover sites had an impact on Reed Warbler annual survival. This result was confirmed by the LRT between the constant model (model 3, Table 1) and our best model $\left(\chi^{2}=4.321, p=0.038\right)$, providing evidence that the climatic variable has an effect on survival. Furthermore, effect size for the meteorological variable of our best 
Table 1 Model selection for estimating survival rates of Reed Warblers

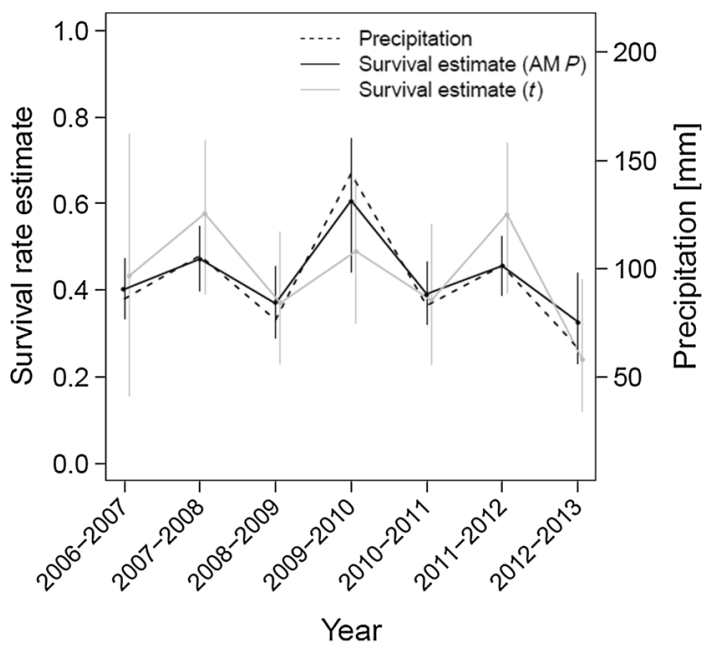

Fig. 2 Survival rates of Reed Warblers in relation to precipitation at autumn stopover sites in Spain and Morocco. Apparent survival rates and 95\% confidence intervals for class M2+ as estimated by the best model incorporating the influence of precipitation at autumn stopover sites (AM $P$; model 1, Table 1$)$ and the time-dependent model $(t$; Model 13, Table 1$)$

model (precipitation during autumn migration) was significant $\quad\left(\beta_{1}=0.073 ; \quad 95 \% \quad\right.$ CI $\quad 0.005-0.141 ; \quad$ ESM Table S2).
Based on $\triangle \mathrm{AICc}$ values of models incorporating meteorological data (models 1, 2, 4-12, Table 1), our results suggest that temperature during the spring and autumn migrations, precipitation during the spring migration and weather conditions at the breeding and wintering grounds do not significantly affect survival estimates for the studied population of Reed Warblers.

\section{Discussion}

Our analyses showed that annual survival of the studied population of Reed Warblers was influenced by precipitation at autumn migration stopover sites: survival declined with lower rainfall. As precipitation levels often correlate positively with vegetation development and primary productivity [measured, for example, by the normalised difference vegetation index (NDVI)] and therefore with food availability in areas with hot climates (Cheke and Holt 1993; Todd et al. 2002; Camberlin et al. 2007; Ockendon et al. 2014), we hypothesise that arid conditions during the summer/autumn in Spain and Morocco may cause limited food availability at these autumn stopover sites, prevent proper refueling and result in lower survival (compare with 
Salewski et al. 2013; Ockendon et al. 2014). Such an explanation is likely considering the dramatic climatic changes which are occurring in the Mediterranean, especially in southern Spain, where many habitats are currently becoming desert-like in late summer as a result of increased temperatures and decreased rainfall (GarcíaMozo et al. 2011; Houghton 2015; Araújo et al. 2016). Stopover sites in the Mediterranean are of prime importance for Reed Warblers due to this species refueling strategy: at these stopover sites they accumulate the energy reserves needed to cross the Sahara immediately before they face this ecological barrier-and not along the whole migration route (Schaub and Jenni 2000). As a result, Reed Warblers are very sensitive to the prevailing environmental conditions at important stopover sites.

Our results are in line with those reported in numerous earlier studies of various avian species that provide evidence for relationships between survival and/or population levels and indices of wet season rainfall at wintering areas (Peach et al. 1991; Baillie and Peach 1992; Schaub et al. 2005, García-Pérez et al. 2014; Ockendon et al. 2014; Johnston et al. 2016) or along migratory routes (LaManna et al. 2012). However, we did not find a similar relationship between survival and precipitation for spring stopover sites or wintering areas. One possible explanation for our results is that in western Africa Reed Warblers usually occupy mangrove forests (where they are the dominant species, although a few other European species, such as Common Chiffchaffs or Willow Warblers also occur; Zwarts et al. 2014), which are not very sensitive to short-term fluctuations in precipitation levels. Ockendon et al. (2014) also did not find a positive correlation between rainy season rainfall and mean winter NDVI for the humid zone, where Reed Warblers from central Europe (but also, for example, Willow and Garden Warblers, House Martins and Spotted Flycatchers) winter and fuel up before their spring migration (the authors did find positive correlations for the arid zone and southern Africa). Variable sensitivity of different habitats to rainfall levels may explain the inconsistent relationships between survival and rainfall in Africa that were found for different bird species (Boano et al. 2004; Salewski et al. 2013; Ockendon et al. 2014; Johnston et al. 2016). Our results are also in line with the earlier findings of Thaxter et al. (2006) and Zwarts et al. (2009), who did not find a significant effect of African droughts on the size of Reed Warbler populations. However, our estimates are based on a 9-year dataset. Obtaining a larger dataset would allow for more extensive analyses examining the relationship between survival and meteorological conditions.

We did not find a significant effect of weather variables during the breeding season on the survival of adult Reed Warblers. This result seems to be consistent with our observations in an earlier study that analysed the survival of birds from our study population during the breeding season (Wierucka et al. 2016): male survival was very high while increased mortality of females was likely to be related to on-nest predation, which needs not be weather dependent. No effect of weather at the breeding grounds on between-year apparent survival was found by Salewski et al. (2013) in several species of European passerines.

Our study revealed that recapture probability was significantly lower for females than for males. This pattern has been found in several studies of Reed Warblers (e.g. Boano et al. 2004; Thaxter et al. 2006) and most likely does not result from differential inter-annual dispersal of both sexes, as the distances birds move between seasons are similar for resident males and females and are not statistically significant (L. Halupka, unpublished data).

We did not find significant differences in survival rates between sexes. This pattern is different from that found in the majority of other bird species, where annual survival is typically higher for males than for females (e.g. Stokke et al. 2005; Low et al. 2010). Interestingly, however, Thaxter et al. (2006) found opposite patterns (higher and lower male survival compared to the females) in two populations of British Reed Warblers, suggesting that sexbased survival and/or emigration may be site-specific in the species.

The overall survival estimate of 0.439 for Reed Warblers in our Polish study site was similar to values reported recently for Reed Warblers from western Europe (0.43-0.47; Johnston et al. 2016). Other studies focusing on Reed Warblers have reported annual survival estimates of between 0.33 and 0.60 (Long 1975; Thaxter et al. 2006). It is important to stress, however, that we found a considerable variation in apparent survival between years at our study site, varying from 0.340 to 0.593 . As summer mortality in our population is low (Wierucka et al. 2016), most deaths must occur during migration or in the wintering areas. As migration is an extremely costly activity (Moore et al. 1990; Sillett and Holmes 2002; Holzschuh and Deutschlander 2016), with birds being subjected to various weather conditions that may negatively influence them, both directly (e.g. extreme temperatures, precipitation, storms) and indirectly (e.g. low food availability), it seems likely that a large proportion of the mortality which occurs in avian species is associated with this stage of the annual cycle. Several studies have provided evidence for this hypothesis (Newton 2006; Bayly et al. 2011; Klaassen et al. 2014, Hewson et al. 2016). For example, Sillett and Holmes (2002) estimated that mortality rates of Blackthroated Blue Warblers Dendroica caerulescens were at least 15 -fold higher during migration than during stationary periods. Future studies estimating survival values for Reed Warblers wintering in Africa would enable a more accurate estimation of mortality rates during migration. 
Intriguingly, our results and conclusions are in agreement with a recent study of satellite-tracked Common Cuckoos Cuculus canorus that showed precisely where bird mortality occurred (Hewson et al. 2016). The authors found that most of the mortality of Common Cuckoos on the Western migratory route occurred in Europe, prior to completion of the Sahara crossing, leading them to suggest that deteriorating conditions at stopover sites in Spain and Morocco were responsible for the decreased survival. The authors concluded that the persistence of the Western migratory route, despite the apparent disadvantages over the Eastern one, indicates that the conditions leading to increased mortality have arisen recently. These data suggest that future climatic warming that causes deterioration of habitat quality in Spain and at other Mediterranean sites may have a profound effect on migratory bird population trends. At the same time, identification of stopover sites experiencing the most severe quality deterioration will be needed in the future to prevent further population declines.

In conclusion, our findings suggest that annual survival of Reed Warblers is affected by precipitation at autumn stopover sites in Spain and Morocco. As rainfall levels have declined dramatically in these areas in recent years (García-Mozo et al. 2011; Houghton 2015; Araújo et al. 2016), we hypothesise that these changes may have affected food availability, resulting in increased mortality. Our results may also indicate that further warming associated with decreased precipitation at autumn stopover sites (as predicted by many climatologists; see Houghton 2015) may result in lower survival of Reed Warblers and hence negatively affect population sizes. On the other hand, a higher productivity of offspring related to climate-driven favourable conditions on the breeding grounds may counterbalance this effect. For example, studies of two populations of Reed Warblers from central Europe (Schaefer et al. 2006; Halupka et al. 2008) revealed that increased temperatures observed in recent years during the breeding season were correlated with a higher number of nestlings produced by breeding pairs. However, as various recent estimations of population trends for the Reed Warbler have produced equivocal results (Ockendon et al. 2012, 2014; Vickery et al. 2014, Inger et al. 2015), further detailed studies are needed.

Acknowledgements We are grateful to Giulia Cassasole, Justyna Chachulska, Monika Czuchra, Beata Czyż, Alicja Dziachan, Stanisław Rusiecki, Magdalena Soboń, Łukasz Tomasik, Paulina Turowicz and Katarzyna Turzańska for their help in the field. We would like to thank to Tomasz Mokwa from the Polish Ringing Centre for the access to the data associated with migratory routes and wintering sites of Reed Warblers. We are indebted to Richard Broughton for constructive comments on the manuscript and for improving the English, and to Grzegorz Neubauer for statistical advice. We are also grateful to Michael Schaub and two anonymous reviewers whose comments considerably improved the manuscript.
The research was financially supported by the Polish State Committee for Scientific Research (Grant 2P04F05330) and the University of Wrocław (Projects 1018/S/IZ/2010-11 and 1073/S/SORM/2012-13). All the study procedures complied with the current laws of Poland.

Open Access This article is distributed under the terms of the Creative Commons Attribution 4.0 International License (http://crea tivecommons.org/licenses/by/4.0/), which permits unrestricted use, distribution, and reproduction in any medium, provided you give appropriate credit to the original author(s) and the source, provide a link to the Creative Commons license, and indicate if changes were made.

\section{References}

Adamik P, Emmeneger T, Briedis M, Gustafsson L, Henshaw I, Krist M, Laaksonen T, Liechti F, Procházka P, Salewski V, Hahn S (2016) Barier crossing in small avian migrants: individual tracking reveals prolonged nocturnal flights into the day as a common migratory strategy. Sci Rep 6:23560

Andueza M, Arizaga J, Barba E, Tamayo-Uria I (2014) Spatial distribution and habitat use of Reed Warblers Acrocephalus scirpaceus during the autumn migration. Behaviour 151:799-817

Araújo PM, de Silva LP, Paiva VH, Ramos JA (2016) Reed Warblers migrating through Portugal: climatic influence on stopover ecology over the last decade. Zoology 119:232-240

Arizaga J, Mendiburu A, Alonso D (2010) Non-breeding Reed Warblers Acrocephalus scirpaceus (Hermann, 1804) in June in southern Europe; local or still migrating birds. Belg J Zool 140:74-76

Baillie SR, Peach WJ (1992) Population limitation in PalaearcticAfrican migrant passerines. Ibis 134:120-132

Bairlein F, Dierschke J, Dierschke V, Salewski V, Geiter O, Hüppop K, Köppen U, Fiedler W (2014) Atlas des Vogelzuges. Ringfunde deutscher Brut- und Gastvögel. AULA-Verlag, Wiebelsheim

Baker AJ, Gonzalez PM, Piersma T, Niles LJ, de Lima Serrano do Nascimento I, Atkinson PW, Clark NA, Minton CDT, Peck MK, Aarts G (2004) Rapid population decline in Red Knots: fitness consequences of decreased refuelling rates and late arrival in Delaware Bay. Proc R Soc Lond B 271:875-882

Balança G, Schaub M (2005) Post-breeding migration ecology of Reed Warbler Acrocephalus scirpaceus, Moustached A. melanopogon and Cetti's Warbler Cettia cetti at a Mediterranean stopover site. Ardea 93:245-257

Bayly NJ, Clark JA, Rumsey SJR (2011) Crossing the Sahara Desert-migratory strategies of the Grasshopper Warbler Locustella naevia. J Ornithol 152:933-946

Bayly NJ, Atkinson PW, Rumsey SJR (2012) Fuelling for the Sahara crossing: variation in site use and the onset and rate of spring mass gain by 38 Palearctic migrants in western Sahel. J Ornithol 153:931-945

Blomberg EJ, Sedinger JS, Nonne DV, Atamian MT (2013) Seasonal reproductive costs contribute to reduced survival of female Greater Sage-grouse. J Avian Biol 44:149-158

Boano G, Bonardi A, Silvano F (2004) Nightingale Luscinia megarhynchos survival rates in relation to Sahel rainfall. Avocetta 28:77-85

Camberlin P, Martiny M, Philippon N, Richard Y (2007) Determinants of the interannual relationships between remote sensed photosynthetic activity and rainfall in tropical Africa. Remote Sens Environ 106:199-216

Cheke RA, Holt J (1993) Complex dynamics of desert locust plagues. Ecol Entomol 18:109-115 
Choquet R, Lebreton JD, Gimenez O, Reboulet AM, Pradel R (2009) U-CARE: Utilities for performing goodness of fit tests and manipulating CApture-REcapture data. Ecography 32:1071-1074

Cooch E, White G (2012) Program MARK: a gentle introduction. www.phidot.org/software/mark/docs/book/. Accessed on 24 Nov 2014

Cormack RM (1964) Estimates of survival from the sighting of marked animals. Biometrika 51:429-438

Cramp JS (1992) The birds of the Western Palearctic, vol 6. Oxford University Press, Oxford

García-Mozo H, Mestre A, Galán C (2011) Climate change in Spain: phenological trends in southern areas. In: Blanco J, Kheradmand $\mathrm{H}$ (eds) Climate change-socioeconomic effects, 1st edn. InTechOpen, Rijeka, pp 237-250

García-Pérez B, Hobson KA, Albrecht G, Cadman MD, Salvadori A (2014) Influence of climate on annual survival of Barn Swallows (Hirundo rustica) breeding in North America. Auk 131:351-362

Geiser S, Arlettaz R, Schaub M (2008) Impact of weather variation on feeding behaviour, nestling growth and brood survival in Wrynecks Jynx torquilla. J Ornithol 149:597-606

Gordo O, Sanz JJ (2008) The relative importance of conditions in wintering and passage areas on spring arrival dates: the case of long-distance Iberian migrants. J Ornithol 149:199-210

Halupka L, Dyrcz A, Borowiec M (2008) Climate change affects breeding of Reed Warblers Acrocephalus scirpaceus. J Avian Biol 39:95-100

Halupka L, Halupka K, Klimczuk E, Sztwiertnia H (2014a) Coping with shifting nest predation refuges by European Reed Warblers Acrocephalus scirpaceus. PLoS One 9(12):e115456

Halupka L, Sztwiertnia H, Borowiec M, Klimczuk E, Leisler B (2014b) Lack of polygyny in Central European populations of Reed Warblers Acrocephalus scirpaceus. Ornis Fenn 91:187-194

Hama F, Gargallo G, Benhoussa A, Zerdouk S, Rguibi Indrissi H (2013) Autumn body condition of Palaearctic trans-Saharan migrant passerines at an oasis in southeast Morocco. Ring Migr 28:77-84

Hewson CM, Thorup K, Pearce-Higgins JW, Atkinson PW (2016) Population decline is linked to migration route in the Common Cuckoo, a long-distance, nocturnally migrating bird. Nat Commun 7:12296. doi:10.1038/ncomms12296

Holzschuh JA, Deutschlander ME (2016) Do migratory warblers carry excess fuel reserves during migration for breeding purposes? Auk 133:459-469

Houghton J (2015) Global warming: the complete briefing, 5th edn. Cambridge University Press, Cambridge

Hurvich CM, Tsai L (1989) Regression and time series model selection in small samples. Biometrika 76:297-307

Inger R, Gregory R, Duffy JP, Stott I, Voříšek P, Gaston KJ (2015) Common European birds are declining rapidly while less abundant species' numbers are rising. Ecol Lett 18:28-36

Jankowiak Ł, Pietruszewska H, Wysocki D (2014) Weather conditions and breeding season length in blackbird (Turdus merula). Folia Zool 63:245-250

Jansen DYM, Wilson AM, Altwegg R (2015) Climatic influences on survival of migratory African Reed Warbler Acrocephalus baeticus in South Africa. Ardea 103:163-174

Johnston A, Robinson RA, Gargallo G, Julliard R, van der Jeugd Baillie SR (2016) Survival of Afro-Palaearctic passerine migrants in western Europe and the impacts of seasonal weather variables. Ibis 158:465-480

Jolly GM (1965) Explicit estimates from capture-recapture data with both death and immigration-stochastic model. Biometrika $52: 225-247$
Klaassen RHG, Hake M, Strandberg R, Koks BJ, Trierweiler C, Exo K-M, Bairlein F, Alerstam T (2014) When and where does mortality occur in migratory birds? Direct evidence from longterm satellite tracking of raptors. J Anim Ecol 83:176-184

Klimczuk E, Halupka L, Czyż B, Borowiec M, Nowakowski JJ, Sztwiertnia H (2015) Factors driving variation in biparental incubation behaviour in the Reed Warbler (Acrocephalus scirpaceus). Ardea 103:51-59

Korner-Nievergelt F, Liechti F, Bruderer B (2002) How does age and body condition affect migratory restlessness and orientation in Reed Warblers Acrocephalus scirpaceus? Ardeola 49:29-37

LaManna JA, George TL, Saracco JF, Nott MP, DeSante DF (2012) El Nino-Southern Oscillation influences annual survival of a migratory songbird at a regional scale. Auk 129:734-743

Leyrer J, Lok T, Brugge M, Spaans B, Sandercock BK, Piersma T (2013) Mortality within the annual cycle: seasonal survival patterns in Afro-Siberian Red Knots Calidris canutus canutus. J Ornithol 154:933-943

Long R (1975) Mortality of Reed Warblers in Jersey. Ring Migr $1: 28-32$

Low M, Arlt D, Eggers S, Pärt T (2010) Habitat-specific differences in adult survival rates and its links to parental workload and onnest predation. J Anim Ecol 79:214-224

Moore FR, Kerlinger P, Simons PTR (1990) Stopover on a Gulf Coast barrier island by spring trans-Gulf migrants. Wilson Bull 102:487-500

Newton I (2006) Can conditions experienced during migration limit the population levels of birds? J Ornithol 147:146-166

Ockendon N, Hewson CM, Johnston A, Atkinson PW (2012) Declines in British-breeding populations of Afro-Palaearctic birds are linked to bioclimatic wintering zone in Africa, possibly via constraints on arrival time advancement. Bird Study 59:111-125

Ockendon N, Johnston A, Baillie SR (2014) Rainfall on wintering grounds affects population change in many species of AfroPalaearctic migrants. J Ornithol 155:905-917

Orłowski G, Hałupka L, Klimczuk E, Sztwiertnia H (2015) Shell thinning due to embryo development in eggs of a small passerine bird. J Ornithol 157:565-572

Peach W, Baillie S, Underhill L (1991) Survival of British Sedge Warblers Acrocephalus-schoenobaenus in relation to West African Rainfall. Ibis 133:300-305

Polak M, Kasprzykowski Z (2013) The effect of weather conditions on the breeding biology of the Eurasian Bittern Botaurus stellaris in eastern Poland. Ethol Ecol Evol 25:243-252

Pollock KH, Nichols JD, Brownie C, Hines JE (1990) Statistical inference for capture-recapture experiments. Wildl Monogr 107:3-97

Procházka P, Policht R (2008) Reed Warbler. In: Cepák J et al (eds) Czech and Slovak bird migration atlas. Aventinum, Prague, pp 416-419

Procházka P, Hobson KA, Karcza Z, Kralj J (2008) Birds of a feather winter together: migratory connectivity in the Reed Warbler Acrocephalus scirpaceus. J Ornithol 149:141-150

Rguibi-Idrissi H, Julliard R, Bairlein F (2003) Variation in the stopover duration of Reed Warblers Acrocephalus scirpaceus in Morocco: effects of season, age and site. Ibis 145:650-656

Robinson RA, Kew JJ, Kew AJ (2010) Survival of suburban blackbirds varies seasonally but not by sex. J Avian Biol 41:83-87

Ruge K (1974) Europäische Schwalben-katastrophe im Oktober 1974: Bitte 1975 auf die Brutbestände achten! Die Vogelwarte 27:299-300

Salewski V, Hochachka WM, Fiedler W (2013) Multiple weather factors affect apparent survival of European passerine birds. PLoS One 8:e59110 
Sanderson FJ, Donals PF, Pain DJ, Burfield IJ, van Bommel FPJ (2006) Long-term population declines in Afro-Palaearctic migrant birds. Biol Conserv 131:93-105

Schaefer T, Ledebur G, Beier J, Leisler B (2006) Reproductive responses of two related coexisting songbird species to environmental changes: global warming, competition, and population sizes. J Ornithol 147:47-56

Schaub M, Jenni L (2000) Body mass of six long-distance migrant passerine species along the autumn migration route. J Ornithol 141:441-460

Schaub M, Jenni L (2001) Stopover durations of three warbler species along their autumn migration route. Oecologia 128:217-227

Schaub M, Kania W, Köppen U (2005) Variation of primary production during winter induces synchrony in survival rates in migratory white storks Ciconia ciconia. J Anim Ecol 74:656-666

Seber GA (1965) A note on the multiple-recapture census. Biometrika 52:249-259

Sillett TS, Holmes RT (2002) Variation in survivorship of a migratory songbird throughout its annual cycle. J Anim Ecol 71:296-308

Stokke BG, Møller AP, Sæther B-E, Rheinwald G, Gutscher H (2005) Weather in the breeding area and during migration affects the demography of a small long-distance migrant. Auk 122:637-647

Sugiura N (1978) Further analysis of the data by Akaike's information criterion and the finite corrections. Commun Stat Theory Methods 7:13-26

Svensson L (1992) Identification guide to European Passerines. Published by the author, Stockholm

Thaxter CB, Redfern CP, Bevan RM (2006) Survival rates of adult reed warblers Acrocephalus scirpaceus at a northern and southern site in England. Ring Migr 23:65-79

Todd MC, Washington R, Cheke RA, Kniveton D (2002) Brown locust outbreaks and climate variability in southern Africa. J Appl Ecol 39:31-42
Tøttrup AP, Klaassen RHG, Kristensen MW, Strandberg R, Vardanis Y, Rahbek C, Alerstam T, Thorup K (2012) Drought in Africa caused delayed arrival of European songbirds. Science 338:1307

Vickery JA, Ewing SR, Smith KW, Pain DJ, Bairlein F, Škorpilová J, Gregory RD (2014) The decline of Afro-Palaearctic migrants and an assesment of potential causes. Ibis 156:1-22

Ward DH, Rexstad EA, Sedinger JS, Lindberg MS, Dawe NK (1997) Seasonal and annual survival of adult Pacific Brant. J Wildl Manage 61:773-781

White GC, Burnham KP (1999) Program MARK: survival estimation from populations of marked animals. Bird Study 46(S1):S120 S139

Wierucka K, Halupka L, Klimczuk E, Sztwiertnia H (2016) Survival during the breeding season: nest stage, parental sex, and season advancement affect Reed Warbler survival. PLoS One 11(3):e0148063

Williams CB (1961) Studies in the effect of weather conditions on the activity and abundance of insect populations. Philos Trans R Soc B Biol Sci 244:331-378

Winkler DW, Luo MK, Rakhimberdiev E (2013) Temperature effects on food supply and chick mortality in Tree Swallows (Tachycineta bicolor). Oecologia 173:129-138

Woodworth BK, Wheelwright NT, Newman AE, Schaub M, Norris DR (2017) Winter temperatures limit population growth rate of a migratory songbird. Nat Commun 8:14812

World Meteorological Organisation (WMO) (2016) WMO statement on the status of global climate in 2015. Report nr 1167. WMO, Geneva

Zwarts L, Bijlsma RG, van der Kamp J, Wymenga E (2009) Living on the edge: wetlands and birds in a changing Sahel. KNNV publishers, Ultrecht

Zwarts L, van der Kamp J, Klop E, Sikkema M, Wymenga E (2014) West African mangroves harbour millions of wintering European Warblers. Ardea 102:121-130 